\title{
The influence of dwelling in the Word within the Southern African Partnership of Missional Churches
}

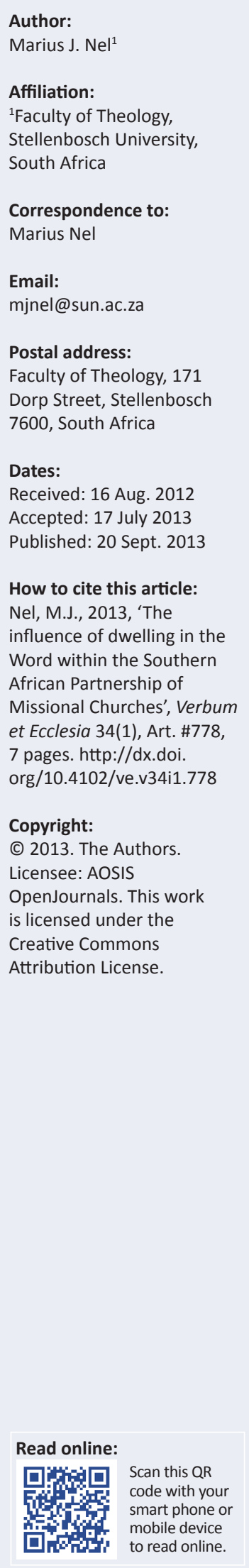

'All of creation dwells within the Word of God, the Word who created us, the Word who redeems us' (Ellison 2009:91). The article evaluated the influence that the communal spiritual practice of dwelling in the Word had in the missional transformation of congregations that formed part of the Southern African Partnership of Missional Churches. It investigated the background, hermeneutic and methodology of dwelling in the Word on the participating congregations. The article concluded that the practice had a profound effect on the theology and missional practice of most of the participating congregations as it had a positive influence on the attitudes and beliefs, minimum knowledge base, and skills of a number of churches leading to spontaneous missional activity, the discernment of a specific missionary calling, and the integration of theory and practice. However, it had not always led to the formation of new faith communities.

\section{Introduction}

The aim of this article is to evaluate the influence that the communal spiritual practice of dwelling in the Word has had on the missional transformation of local churches that form part of the Southern African Partnership of Missional Churches (SAPMC). After a brief introduction to the SAPMC, the importance, hermeneutic and methodology and influence of dwelling in the Word on congregations participating in the SAPMC will be analysed before reaching a conclusion regarding its significance.

\section{Southern African Partnership of Missional Churches}

The SAPMC, in partnership with the Church Innovation Institute (CI) from St Paul (Minneapolis, USA), has been an important missiological influence within the Dutch Reformed Church (DRC) and other participating churches in Southern Africa since 2004. In 2008, there were 110 congregations, representing $9.5 \%$ of all DRC congregations involved in the SAPMC (Hendriks 2009:109). The SAPMC is not a fixed programme with distinct steps leading to generic missional outcomes (Hendriks 2009:109-119). It is rather a shared journey of spiritual formation and discernment shaped by communal spiritual practices. The goal of the 3-year journey of spiritual discernment is to free congregations from a narrow focus on the maintenance of Christendom to being innovative missional churches in their specific time and location (Keifert 2006:17).

The SAPMC observes three key communal spiritual practices:

- Dwelling in the World is a practice that focuses on the interactions - deliberate and spontaneous - of believers over a 7-day period with others (strangers and acquaintances). Its aim is to help believers discern that their everyday encounters with others are missional opportunities for conveying God's peace to those with whom they interact.

- Plunging refers to the practice of deliberately crossing a congregation's cultural boundaries (which includes conceptual and geographical boundaries) to enter the world of those with whom members of the congregation do not ordinarily interact (Mouton 2010:1-2).

- Dwelling in the Word is the practice of a repeated communal listening to a passage of Scripture over long periods of time in order to enable a Christian community to undertake its decisions and actions in line with the biblical meta-narrative (Keifert 2006:163).

As the focus of this article is specifically on the practice of dwelling in the Word, it is necessary to give a brief overview of its methodology. The methodology consists of reading a chosen text aloud in a group. Church Innovations (CI) has always read Luke 10:1-12 since a planning weekend of the Minnesota Council of Indian Work of the Episcopal Diocese of Minnesota in 1995 (Keifert 2006:69). After the initial reading of the text, time is given for silent reflection on its meaning. Every group member is then instructed to find a 'reasonably friendly-looking stranger' with whom to share what has been gleaned in their personal reflection on the text. After sharing in pairs, members give feedback to the group on what they have heard from their respective 
partners. The group is then invited to discover the meaning of the text for their specific context by asking: 'What is God up to here?' and 'What is the Word of God for us in this place and time?' (Keifert 2009:21). These two questions reflect the specific theological aim of dwelling in the Word as to invite the participants thereof into the world of the text, and in so doing to join in the mission of God (the missio Dei) to the world (Keifert 2006:36-37). As such, it is part of the SAPMC journey to discern to whom God is specifically sending the participants as individuals and as a faith community. In the SAPMC, the expressed aim of the process of corporate spiritual discernment through dwelling in the Word is to discover the preferred and promised future of God for a specific faith community (Keifert 2006:64).

\section{The importance of dwelling in the Word}

The importance of the practice of dwelling in the Word in the transformation of maintenance-orientated churches into missional churches is clear from the experience and research of both the Partnership for Missional Churches (PMC) in the USA and the SAPMC in Southern Africa.

Dwelling in the Word in the Partnership for Missional Churches Reflecting on the work of CI after more than two decades in the USA, Pat Keifert, CI's founder and president, considers the various ways that his institute has enhanced the capacity of churches to dwell in the Word to be its most significant innovation for building local churches' missional capacity (Keifert 2006:69). The reason for Keifert's conclusion is that the practice of dwelling in the Word stimulates the ability of church leaders to imagine their everyday life within the narrative of Scripture, which in turn is a key commonality of flourishing missional congregations in the USA, according to research undertaken by CI. The other key commonalities are that missional congregations (1) decide to change from maintenance or 'having a mission', to being and doing mission, (2) learn how to make disciples in the age of consumerism and (3) discover how to receive change as God's gift for Christian growth (SAPMC 2008:7).

\section{Dwelling in the Word in the Southern African Partnership of Missional Churches}

In 2009, the national committee of the SAPMC undertook a follow-up study of $10 \%$ of the congregations who had participated in the SAPMC programme since 2004 (Niemandt 2010:397-412). Ten DRC congregations (Constantiakruin, Doornpoort, Helderberg, Joubertina, Kenridge, Paarlberg, PE-Hoogland, Sonnekus, Weltevreden, StellenboschMoedergemeente) as well as congregations of the Netherdutch Reformed Church (NHK) (Kempton Park East) and the Congregational Church (Pniel) were requested to complete a questionnaire on the effect of their participation in the SAPMC on their congregation's missional culture. The questionnaire consisted of specific questions to 24 respondents from three specific social groups who differed in their levels of commitment to the congregation. The most committed group ('family') formally and informally decides what gets done in the congregation, the second group ('inside strangers') attends the functions of the congregation but does not participate in its leadership processes, whilst the third group ('outside strangers') is not involved in the everyday life of the congregation at all (Keifert 2006:77-78).

The data of the different questionnaires were subsequently summarised in a 91-page report presented to the national committee by Mouton (2009). Of the twelve congregations studied, only two (DRC Kenridge and DRC StellenboschMoedergemeente) did not specifically refer to the importance of dwelling in the Word in the transformation of the missional culture of the congregation in their respective reports. Although two other congregations (DRC Doornpoort and DRC PE Hoogland) did not refer to the practice of dwelling in the Word by name, they did describe the methodology of the practice itself. The other congregations explicitly mentioned the important influence of the practice of dwelling in the Word on their congregations. The emphasis on the importance of the practice in the 2009 follow-up study supports the experience of the leadership of the SAPMC as expressed during the 2009 national meeting of participating congregations, regarding its specific importance for rekindling the missionary imagination of congregational leaders in Southern Africa. It is noteworthy that a number of congregations in the follow-up study explicitly mentioned that Scripture has been given a new, central position in their congregation's decision-making process due to the practice of dwelling in the Word.

Given the stated importance of the practice of dwelling in the Word for the missional transformation of congregations in the PMC and the SAPMC (the importance of dwelling in the Word), it is important to understand and evaluate its underlying hermeneutic and methodology (the hermeneutic and methodology of the practice of dwelling in the Word) as well as the way in which it has transformed missiological practices of congregations (the influence of the practice of dwelling in the Word on congregations of the Southern African Partnership of Missional Churches).

\section{The hermeneutic and methodology of the practice of dwelling in the Word}

In order to evaluate the theological influence of the practice of dwelling in the Word it is important to understand the metaphor governing its use of Scripture as an exercise in communal spiritual discernment before asking whether it applies Scripture in a hermeneutically responsible manner.

\section{Dwelling in the Word as metaphor for the role of Scripture}

The work of Lesslie Newbigin - a major influence on the theology of the PMC (Keifert 2006:18) - provides a key for understanding the role of Word-dwelling in the PMC, even though Newbigin did not explicitly use the phrase dwelling in the Word, nor develop a specific methodology for indwelling in the Word like the one that the PMC utilises. 
In The gospel in a pluralistic society, Newbigin (1989) wrestles with the question of how the unique biblical story can engage the prevalent secular worldview. He concludes that it can only do so through the witness of a community that in continuity with the biblical witnesses indwells the story that the Bible tells. Utilising the concept 'indwell' - a key epistemological concept of Michael Polanyi - Newbigin (1989:97-99) argues that the important aspect in the use of the Bible by a witnessing community is not to understand the text, but to understand the world through the text. Whilst it is possible to consider the Bible as an object for analysis and interpretation, and to examine it without allowing it to examine its readers, the proper relationship with the Bible for a community of faith is to 'indwell' it by allowing it to furnish its readers with a new plausibility structure. This plausibility structure takes the form of a story that is embodied in a historical community called by God in continuity with those who have gone before them from the very beginning of the story the Bible narrates (Newbigin 1989:99).

In terms of Newbigin's concept of 'indwelling', the practice of dwelling in the Word stimulates the imagination of believers to live according to what is plausible according to the Bible. It invites believers to imagine their everyday life within the Biblical narrative of God's continuing mission to the world by creating analogies between what is described in the biblical text and things elsewhere in the world (Duty 2009:133-134; Keifert 2006:69). The focus of dwelling in the Word is therefore on awakening the missionary imagination of a congregation and not just on repeating the Biblical missionary imperative (see Martin 2008:70).

The insight of Newbigin regarding the use of Scripture in order to challenge the modern secular worldview is an important one for evaluating the practice of dwelling in the Word. It clarifies that dwelling in the Word is not primarily an exercise in the critical scientific exegesis of Scripture, but rather one in communal spiritual discernment. Johnson (1996:109-110) defines discernment as the habit of faith by which believers are properly disposed to hear God's Word, and to respond to that Word in the practical circumstances of their lives. Spiritual discernment, as practiced in the SAPMC, attends to three sources for spiritually relevant knowledge: (1) tradition, especially Scripture, (2) culture and society and (3) the experience of the faithful, both personal and communal (Keifert 2009:21). In the continual application of the key communal practices of the SAPMC (dwelling in the Word, dwelling in the world and plunging into new cultural contexts), these three sources are engaged in order to discern what God is doing in the present, and how the church can participate in God's mission to the world. Whereas a critical historical critical reading of a text emphasises the historical and cultural distance between text and contemporary readers (Van Eck 2008:1176), dwelling in the Word, as an exercise of spiritual discernment, deliberately eliminates this distance. Its aim is to allow the text to examine its readers and to provide them with a new way of understanding the world and their mission therein.
As a practice of communal spiritual discernment, dwelling in the Word uses Scripture differently than it is usually utilised in many contemporary Western faith communities. Rather than speaking about Scripture, it aims to listen to Scripture. Instead of an expert (the professional minister or academic scholar) reading the text for others in order to discover the generally accepted meaning of a text, Scripture is repeatedly read with others in order to discover the variety and richness of its meaning. Research undertaken by the British and Foreign Bible Society in 1997 for instance found that $18 \%$ of regular churchgoers (defined as people attending church at least twice a month) had never read anything in the Bible for themselves in their entire lives. Another 14\% had not read the Bible for themselves in that particular year (Green \& Robinson 2008:89). As a communal way of reading Scripture, dwelling in the Word specifically aims to address the individualistic reading of Scripture that characterises much of late modernity's use of Scripture in the West, in that Western Christians have forgotten how to dwell in the Word together and how to share their thoughts about God out loud. If they do dwell in the Word, they do so quietly and alone (Ellison 2009:92).

\section{The use of Scripture in dwelling in the Word}

In answering the question whether dwelling in the Word is a hermeneutically responsible way of reading Scripture, it is important to clarify just who determines whether Scripture has been read in a theologically responsible manner. In this regard, David Tracy (1981:3-46) makes a well-known distinction between three different 'publics' (or spheres) in which theologians may function, namely the academy, the church and society. All three publics operate within their own problem-consciousness, their own logic of investigation, their own ethos and highest loyalties, their own mode of argumentation and conception of truth. A responsible reading by one public need therefore not necessarily be considered a responsible reading by the other two.

The church was historically the primary context of Christian theology, whilst society at large was often included in the sphere of the believing community in the time of the corpus christianum. After the Enlightenment the academy, which in many instances had developed within the sphere of the influence of the church, began to occupy an independent position vis-à-vis the church. The result was that within the post-enlightenment world it was academia that determined how Scripture should be read (i.e. historically critically) (Martin 2008:3-9). According to this modern view, theology was done primarily within academia and only applied in congregations (Keifert 2009:15).

Utilising Tracey's distinction one could argue that the believing community can determine its own rules for the reading of Scripture for its unique purposes (such as spiritual discernment). There is no doubt that reading the Bible from the perspective of a believing community that is focused on theological concerns is serious reading (Martin 2008:71-91). It can even be considered 'ultimate reading' in 
the words of Van Zyl (2008:137). Conversely, if a theological reading of a text was undertaken by the church only for its own edification according to its own exegetical rules, it would negate the missional aspect of the practice of dwelling in the Word. The manner in which Scripture is read would become a boundary-marking instead of a boundary-crossing exercise. As such it would ignore Keifert's (2009:11-26) plea that congregations should return to the theological conversation with society and academia. For this reason, even though dwelling in the Word is not an exercise in the historical critical exegesis of Scripture (the dominant exegetical approach in academia), but rather an exercise in communal spiritual discernment, it is still important to give an account of the underlying hermeneutic of its reading of the Bible. It is important to note that the reading of the text by dwelling in the Word does engage critical readings of the text by specifically asking what a New Testament scholar would make of certain aspects of the text and incorporating these insights into future readings of the text.

As an exegetical method, dwelling in the Word can be classified as a form of reader-response criticism practised by average, everyday readers (in contrast to informed, 'expert' readers who have received specialised training in reading ancient texts) (Fowler 1992:52). Dwelling in the Word can also be considered a conservative reader response approach, in that whilst acknowledging the role of the reader in the process of making meaning, it focuses on the various ways the text itself invites the reader into the production of meaning (Vanhoozer 1995:307). In terms of the distinction that Steiner (1979:423-452) makes between 'readers' and 'critics', dwelling in the Word is practised by 'readers'. Whereas a critic is someone who probes, questions, challenges and 'masters' the text, a reader honours, reveres, and 'serves' the text that he or she is reading.

Whilst dwelling in the Word actively encourages multiple readings of a text, in practice it regards the meaning of a given text as polyvalent, but not omnivalent, in that the participants of Word-dwelling, as a communal readerresponse reading of a text, have their individual readings shaped by the community of which they are members. This is not unique to the practice of dwelling in the Word, as readings of texts by both readers and critics are governed by the rules of their respective communities (Fowler 1992:52). It is precisely this communal reading of Scripture, as practiced through dwelling in the Word, which is of great importance in evaluating its use of Scripture. In dwelling in the Word, every reader's understanding of a text is shaped by both their initial partner's understanding of what had been related to them and by the communal discussion of all the readings by the group. In practice, this tends to eliminate most esoteric and out of context readings of texts. This meaning forming process is furthermore not a once-off occurrence, but rather one repeated in different groups, times and spaces to facilitate a more refined reading of Scripture.

One aspect of the practice of dwelling in the Word that deserves greater attention is the explicit incorporation of the biblical meta-narrative of God's mission to redeem the entire world in its reading of a given text. At present the SAPMC and the practice of dwelling in the Word presuppose a high level of biblical literacy. It is, however, questionable how many modern readers in an increasingly late-modernistic South Africa are truly familiar with the biblical meta-narrative of God's mission to redeem all of creation. Projects that focus on reading entire Bible books and specific topics within the scope of the entire biblical narrative are therefore crucially important since they incorporate the complex intratextual and intertextual relationships of biblical texts (even though they do not necessarily incorporate the extrabiblical intertexture of a text). The deliberate incorporation of the intratextual (the entire book of which a text is part) and intertextual relationships (the entire canon) of the texts read in dwelling in the Word would act as an additional interpretative safeguard in the reading process.

\section{The influence of the practice of dwelling in the Word on congregations of the Southern African Partnership of Missional Churches}

It is clear from the 2009 evaluation of congregations that have been part of the SAPMC since 2004 that the practice of dwelling in the Word, as a key aspect of the SAPMC journey, has had a profound effect on the missional identity and practice of participating congregations (see Mouton 2009). It is not always possible to separate the specific influence of dwelling in the Word from the general influence of the SAPMC programme as a whole from the 2009 follow-up. However, it is clear from numerous evaluations done at cluster meetings of the SAPMC that the practice of dwelling in the Word is the key aspect of the SAPMC programme that has led to the above-mentioned missional transformations in participating congregations. In evaluating this influence, it is important to take note of the emergence of spontaneous missional behaviour in the SAPMC congregations, the participating congregations' ability to discern their specific mission, the formation of new faith communities, and the integration of theory and practice in dwelling in the Word.

\section{Dwelling in the Word and the emergence of spontaneous missional behaviour}

A major trend that has emerged in congregations that participate in the SAPMC and that have prioritised dwelling in the Word, is that a growing number of their members have been empowered to begin their own spontaneous, unstructured ministries. These ministries often function outside of congregational structures. A similar trend has emerged in a number of congregations that form part of the Northern cluster of the SAPMC (2007-2009), but were not part of the follow-up study of 2009 ( $\mathrm{Nel} \mathrm{2009:14-15).} \mathrm{The}$ traditional Christendom understanding of missions as a specialised task organised by a designated committee and performed by an officially sanctioned outreach programme 
has thus been thoroughly deconstructed in a significant number of congregations that have participated in the SAPMC. It has been replaced by an understanding of mission as being a lifestyle of dwelling in the Word of God (i.e. sharing in God's missio Dei in all aspects of life by all Christians). Dwelling in the Word has thus become more than a specific practice with a fixed methodology. It has become a new way of living (dwelling) in that believers enact the mission of God as expressed by the Word in their everyday lives. In the SAPMC, the concept of 'dwelling' of CI has been translated with the Afrikaans for 'walking' (om te wandel in die Woord) rather than as 'living' or 'remaining'. This has strengthened the conviction that being missional should be a lifestyle and not a programme or event.

The 2009 summary by Mouton contains a number of quotations that reflect this trend: DRC Constantiakruin - 'It is surprising that ministries developed from the ground up without the minister or church council having to drive it' (Mouton 2009:11). DRC Doornpoort - 'Doing the will of God happens spontaneously when others come across our paths' and 'there is a larger involvement by self-initiated missionary programmes' (Mouton 2009:15, 21). DRC Helderberg - 'We have no control over it. We have no control over how much funds, that would have been administrated by the church council in the past, now flow directly to projects' (Mouton 2009:24). DRC Joubertina - 'There are numerous lay members who take their own initiative' and 'people do not wait for the church council and leaders to take the initiative' (Mouton 2009:26, 29). NHK Kempton Park East - 'Numerous practical and spontaneous examples of people living as disciples in and outside our church' (Mouton 2009:34). DRC Paarlberg 'Our mission field is not about identifiable projects but rather about where we are every moment of the day' (Mouton 2009:58).

The negation of the clear distinctions between ministers and congregants, and the development of the ability to imagine how God's kingdom can be enacted in their own personal context by dwelling in the Word, have thus had a significant impact on the manner in which congregations structure and fund their ministries. Where believers have had their imaginations shaped by the practice of dwelling in the Word, and have been trusted to discern God's will as a group for themselves, they also feel empowered to act accordingly without necessarily seeking the sanctification of a church governing body. Whilst this trend does not mean that all organised outreach programmes have been terminated in participating congregations (the 2009 summary mentions a number of such programmes), it does reflect a growing realisation that the missional commitment of congregants is shifting from formally organised to informal, spontaneous actions. It is important to note that the two congregations (DRC Stellenbosch and DRC Kenridge) that did not specifically note the importance of dwelling in the Word in the 2009 report also contained a lack of references to the above-mentioned emergent trend.
DRC Kenridge - 'We hear almost nothing of the daily, spontaneous integration of faith and life'; and 'it struck us that there is no reference to the implications of discipleship for the daily work of members' (Mouton 2009:44).

DRC Stellenbosch - 'In terms of disciples as followers of Jesus Christ who are sent into their concrete, daily lives, we find a rigidity in the responses' (Mouton 2009:85). There is no doubt that this transformation has also been helped by the way the programme of the SAPMC resonates with an increasingly postmodern society in South Africa.

The critical questions in regard to the manner which dwelling in the Word has led to spontaneous, unstructured ministries are how sustainable these ministries will prove to be and whether they will lead to the demise of the organised church, as Barna (2005:48-49) has suggested.

\section{Dwelling in the Word and participating in the missio Dei}

It is clear from the 2009 follow-up study that the SAPMC, with dwelling in the Word as a key aspect of the discerning process, has had a tremendous positive impact on the participating congregations' ability to discern just where God is specifically calling them to participate in his mission to the world. Along with plunging, it has also increased their willingness and ability to cross ethnic, economic and social boundaries in order to reach the specific communities to whom they have been sent.

It is interesting that the congregations in the follow-up study did not define their specific missional focus (to whom God is sending them) in terms of a specific action or ministry, but rather in terms of a broad adaptation of the culture of the congregation in order to reach a specific group that was not previously part of the different congregations. They had discerned that God was not sending some of them, but rather all of them as a faith community to others. In this sense, the Afrikaans translation of Missional Churches as Gestuurde Gemeentes (literally 'sent congregations') has proven to be an apt one. Examples of the different communities to which the respective congregations have reached out are: DRC Constantiakruin (English-speakers and those with emotional wounds), DRC Doornpoort (youth), DRC Joubertina (new arrivals in the district), DRC Sonnekus (different races), DRC Stellenbosch-Moedergemeente (students), NHK Kempton Park East (residents of a caravan park) and Pniel Congregational Church (unchurched youth).

\section{Dwelling in the Word and the formation of new faith communities}

An important missional aim of the practice of dwelling in the Word is that it must move through the permeable boundaries of the congregation into the larger community (Ellison 2009:94). In practice, other readers from the destination should also be invited to dwell in the Word so that the Word of God can create a new faith community that discerns the 
will of God together. A missional reading of Scripture is not only determined by why it is read (to discover the nature of the missio Dei) but also by whom and where it is read. A true missional reading is thus one where Scripture is read together with those to whom the church has been sent in their context, in order to discern God's will together. This approach negates the danger inherent to all discernment processes in that one group, or individual, will coerce others to do their will by invoking the language of 'God told me to ...' The PMC therefore envisages the process of dwelling in the Word not as closed or limited, but rather as open and everexpanding as it continually invites others into the discerning community that practises the continual communal listening to Scripture. Engaging in Word-dwelling and corporate, meaningful worship with 'strangers' brings strangers from different communities into a shared identity around Christ, which stimulates their Christian imaginations and creates a shared sense of purpose and a willingness to take risks for the sake of their common faith (Ellison 2009:98).

In practice, however, none of the congregations that were part of the follow-up study of SAPMC has reported practising dwelling in the Word in this manner. Dwelling in the Word has thus encouraged congregations to cross boundaries, but not necessarily to create new faith communities. It is also disappointing to note that few congregations have succeeded in forming lasting relationships with other faith communities (DRC Sonnekus, DRC Kenridge and DRC Constantiakruin being notable exceptions). It is, however, clear that the practice of dwelling in the Word does have tremendous potential for deconstructing the traditional boundaries and power hierarchies that characterise many traditional missional approaches and for creating a new Word-based community with a common identity and purpose. What dwelling in the Word accomplishes within a faith community, it can also accomplish between two different communities. The practice of dwelling in the Word creates an ever-expanding community that shares a common reading of Scripture (i.e. who dwell together in the world according to the Word). It begins with an individual reading, before incorporating a stranger and becoming a shared reading of a group. As more groups are formed in a congregation that dwell in the same text, the community of those dwelling together in the Word (and thus sharing a common mission) is continuously enlarged. For this reason, the practice of plunging should also incorporate communal Word-dwelling opportunities. An important caveat in this regard is that in communities with low literary levels the repeated retelling and enactment of a specific text should replace the individual reading of the text.

\section{The integration of the theory and practice in dwelling in the Word}

An important aspect of the practice of dwelling in the Word that came to light in the reflection on its influence during the 2009 conference of participating SAPMC congregations is that it develops the missional skills, attitudes and behaviours of its practitioners. In other words, dwelling in the Word does not only provide a rationale for a congregation's mission. It also teaches them the necessary skills. Whereas congregations tend to struggle to implement a programme for teaching missional skills after a long discerning phase (Nel 2006:40-41, 48), dwelling in the Word addresses this problem by actively developing the required skills to be missional whilst discerning God's will for a specific faith community.

Dwelling in the Word teaches and confirms the following skills, attitudes and behaviours:

- Group members practice reaching out and sharing their faith with people they do not necessarily know well (the 'reasonably friendly-looking stranger' in the group).

- Interpreting the text becomes the responsibility of all in the community, and not only of those considered experts in exegesis.

- Members practice the skill of listening to others and articulating their partners' insights.

- The communicative playing field is intentionally levelled. Those who are naturally reluctant to speak in groups are helped to do so by not having to share their own personal thoughts, whilst those who tend to dominate discussions are constrained by their having to share the insights of others.

- Strong emotions are negated as all insights are stated in the third person.

- Reading, discussing and reflecting on the Word become more important than concluding the 'business' part of church meetings.

- The repeated reading of a specific text creates a shared sense of purpose and willingness to take risks for the sake of their faith amongst the practitioners of dwelling in the Word. Over time dwelling in the Word shapes a group's collective imagination. It defines who they are in relationship to one another and sometimes who they are over against everyone else in the world (Keifert \& Ellison 2008:8).

- Word-dwelling develops the skill of interpreting the Word with others and provides a language for sharing thoughts with each other (Ellison 2009:92, 98). Although it is a metaphoric dwelling, it manages to create a sense of community and shared culture. Certain words begin to remind the dwellers of certain things and verbal shorthand develops (Keifert \& Ellison 2008:8).

- The sharing with another is the first filter for esoteric, wayout interpretations of Scripture.

- Honest reporting and fair access to the conversation builds trust in the new community (Keifert \& Ellison 2008:11).

\section{Conclusion}

It is clear from the 2009 follow-up study that the practice of dwelling in the Word has had a profound effect on the theology and missional practice of most of the participating congregations. In comparison to the earlier study by $\mathrm{Nel}$ (2006) of 17 congregations implementing a strategic missional planning process, the 12 congregations in this follow-up study revealed that the SAPMC journey has led to a number of unique outcomes. The difference between a congregational analysis and strategic planning process in developing a missional strategy (Nel 1994) and the process of the SAPMC becomes especially clear when the reports of 
the NHK Gemeente Kempton Park East, which undertook both processes (Mouton 2009:33-43; Nel 2004:134-152), are compared. Prior to joining the SAPMC, the NHK Gemeente Kempton Park East had been part of an extensive strategic planning process that revitalised the congregation's missional involvement. However, it did not lead to spontaneous missional activities, the discernment of a specific missionary calling, the formation of new faith communities or the integration of theory and practice. ${ }^{1}$

In practising dwelling in the Word (preferably with the same text) over long periods of time and diverse moments in the process of spiritual discernment, members of local churches have begun to imagine their lives being lived within the presence of the living, triune God. They now see and experience the world, especially their immediate community, and those with whom they share their lives, as God does. Within this imagination, they experience both the at-hand-ness of the reign of God and its clear not-in-handness (Duty 2009:137; Keifert 2006:70-71).

A major strength of the practice of dwelling in the Word is the manner in which it integrates theology and practice. Over time, these attitudes and beliefs, minimum knowledge base, and skills shaped by the habits of dwelling in the Word have transformed a number of churches into missional ones (Keifert 2006:70). Whilst the transformation of the institutionalised post-Christendom church in Southern Africa is not yet complete (cf. 5.3), the process of becoming a truly missional church has made significant strides.

\section{Acknowledgements Competing interests}

The author declares that he has no financial or personal relationship(s) that may have inappropriately influenced him in writing this article.

1.The DRC Potgietersrus South also participated in both processes but was not part of the 2009 SAPMC follow-up study. A discussion of this article with $\mathrm{Dr}$ C. Harris (the minister of the congregation during the period of both processes) confirmed that spontaneous missional activities, the discernment of a specific missionary calling, and the integration of theory and practice-occurred only after the congregation joined the SAPMC.

\section{References}

Barna, G., 2005, Revolutionaries - Finding vibrant faith beyond the walls of the sanctuary, Tyndale House, Carol Stream.

Duty, R.W., 2009, 'Scripture, Christian imagination, and the testimony of experience in moral conversation', in P. Keifert (ed.), Congregations: A nested vision for learning new habits, in testing the spirits - how theology informs the study of congregations, pp. 13-26, Eerdmans, Grand Rapids.

Ellison, P.T., 2009, 'Word-dwelling, deep listening, and faith-based moral conversations', in P. Keifert (ed.), Testing the spirits - How theology informs the study of congregations, pp. 91-108, Eerdmans, Grand Rapids. PMid:19835106

Fowler, R.M., 1992, 'Reader-response criticism: Figuring Mark's reader', in J.C. Anderson \& S.D. Moore (eds.), Mark \& method - New approaches in Biblical studies, pp. 50-83, Fortress Press, Minneapolis. PMid:10121656

Green, C. \& Robinson, M., 2008, Metavista: Bible, church and mission in an age of imagination, Authentic, Colorado Springs.

Hendriks, J.H., 2009, 'Trauma and conflict as prerequisites for identity transformation: Lessons from the Southern African Partnership for Missional Churches', Nederduits Gereformeerde Teologiese Tydskrif 50(1 \& 2), 109-119.

Johnson, L.T., 1996, Scripture and discernment - Decision making in the Church, Abingdon Press, Nashville.

Keifert, P., 2006, We are here now - A new missional era, Eagle: Allelon Publishing, Eagle.

Keifert, P., 2009, 'The return of the congregation to theological conversation', in P. Keifert (ed.), Congregations: A nested vision for learning new habits, in testing the spirits - How theology informs the study of congregations, pp. 13-26, Eerdmans, Grand Rapids.

Keifert, P. \& Ellison, P., 2008, Dwelling in the Word, St. Paul: Church Innovations Institute, St. Paul.

Martin, D.B., 2008, Pedagogy of the Bible - An analysis and proposal, John Knox Press, London.

Mouton, D., 2009, Leesverslae van gemeentes, Unpublished report, Communitas, Stellenbosch.

Mouton, D., 2010, 'To plunge when congregations cross their boundaries', unpublished paper delivered at annual meeting of the SA Missionary Society, Bloemfontein, 17 th January.

Nel, M., 1994, Gemeentebou, Orion, Johannesburg.

$\mathrm{Nel}, \mathrm{M} ., 2006$, Stories van hoop - Gemeentes wat in hulle konteks 'n verskil maak en hoop bring, CUM, Vereeniging.

Nel, M.J., 2009, 'Vier Noordelike gemeentes beleef wedergeboorte', Kruisgewys 9(4), $14-15$.

Niemandt, C.J.P., 2010, 'Five years of missional church: Reflections on missional ecclesiology', Missionalia 38(3), 397-412.

Newbigin, L., 1989, The gospel in a pluralistic society, Eerdmans, Grand Rapids.

Smit, D.J., 1988, 'Theology as a critical account of personal faith?', in J. Mouton, A.G. van Aarde \& W.S. Vorster (eds), Paradigms and progress in theology, pp. 91-112, HSRC Studies in Research Methodology, HSRC, Pretoria.

Steiner, G., 1979, 'Critic/reader', New Literary History 10, 432-452. http://dx.doi. org $/ 10.2307 / 468921$

Tracy, D., 1981, The Analogical Imagination: Christian Theology and the Culture of Pluralism, Crossroad Publishing Company, New York.

Van Eck, E., 2008, 'Een teks - meerdere betekenisse, Hoe lees ons die Bybel?', Hervormde Teologiese Tydskrif 64(3), 1155-1185.

Vanhoozer, K.J., 1995, 'The reader in New Testament interpretation', J.B. Green (ed.), Hearing the New Testament - Strategies for interpretation, pp. 301-328, Eerdmans, Grand Rapids.

Van Zyl, H.C., 2008, 'Reading the New Testament from a theological perspective', Acta Theologia 28(2), 133-145. 